\title{
Sistema agroforestal coquia-mezquite establecido en suelos del Distrito de Riego Tulancingo, Hidalgo, México*
}

\section{Kochia-mesquite agroforestry system established in soils Irrigation District Tulancingo, Hidalgo, Mexico}

\author{
Miguel Ángel Sánchez Hernández ${ }^{1}$, Elizabeth Hernández Acosta, David Cristóbal Acevedo², Miguel Uribe Gómez² ${ }^{2 \S}$ Prócoro \\ Díaz Vargas ${ }^{2}$ y Alejandro Lara Bueno ${ }^{2}$ \\ ${ }^{1}$ Posgrado en Ciencias en Agroforestería para el Desarrollo Sostenible- Universidad Autónoma Chapingo. Carretera. México - Texcoco km 38.5, Chapingo, Texcoco C. \\ P. 56230, Estado de México. Tel: 595952 1540. ${ }^{2}$ Universidad Autónoma Chapingo. Carretera. México- Texcoco km 38.5, Chapingo, Texcoco. C. P. 56230, Estado de \\ México.Tel5959521540.(elizahac@gmail.com,cristobalacevdo@yahoo.com.mx; migueluribe123@gmail.com; procoro10@hotmail.com; alarab_11@hotmail.com). \\ ${ }^{\S}$ Autor para correspondencia: migueluribe123@gmail.com.
}

\section{Resumen}

En el Distrito de Riego 028 (DR028) Tulancingo, Hidalgo, desde hace más de 50 años los agricultores utilizan aguas residuales para elriegodecultivos forrajeros. Específicamente, en el ejido San Nicolás Cebolletas, cuyo principal problema es el costo del bombeo para el riego, y en el ejido Santa Ana, donde la salinidad de los suelos comienza a ser evidente en algunas parcelas. El presente trabajo se planteó como objetivo caracterizar física y químicamente (de acuerdo con la NOM-021-RECNAT-2000) los suelos para establecer un sistema agroforestal con una especiemaderabley una agrícola, adecuadas a las condiciones de esa área. Paralelamente, se realizaron talleres participativos para involucrar y considerar la opinión de los productores en cuanto a la selección de las especies. Los resultados mostraron que los suelos nopresentan deficiencias nutrimentales, pero los porcentajes de materia orgánica $(\mathrm{MO})$, el contenido de nitrógeno inorgánico $(\mathrm{N})$ y de metales pesados fueron bajos, la textura de los suelos fue franca. En esas condiciones, se propuso establecer el sistema agroforestal (coquia-mezquite) bajo el diseño de árboles en linderos. De acuerdo con los resultados obtenidos tanto del análisis de los suelos como del costo de la instalación (5 890 pesos) y del rendimiento (46.7 $\left.\mathrm{tha}^{-1}\right)$, se concluyó que la

\section{Abstract}

In the Irrigation District 028 (DR028) Tulancingo, Hidalgo, for more than 50 years ago farmers use wastewater to irrigate forage crops. Specifically, in the common San Nicolás Cebolletas, whose main problem is the cost of pumping for irrigation, and the common Santa Ana, where the salinity of the soil begins to be evident in some plots. This work was proposed objective characterize physically and chemically (according to the NOM-021-RECNAT-2000) soil to establish an agroforestry system with a timber species and suitable to the conditions of the agricultural area. In parallel, participatory workshops to engage and consider the opinion of producers in the selection of species were performed. The results showed that the soils have nutritional deficiencies, but the percentages of organic matter (MO), the content of inorganic nitrogen (N) and heavy metals were low, the soil texture was frank. Under these conditions, it was proposed to establish the agroforestry system (kochia-mesquite) under the design of trees in boundaries. According to the results of both the soil analysis and the cost of installation (5 890 pesos) and yield $\left(46.7 \mathrm{t} \mathrm{ha}^{-1}\right)$, it was concluded that agroforestry plantation (kochia-mesquite) is technically acceptable for this soil types, in addition to showing environmental and economic benefits.

\footnotetext{
* Recibido: diciembre de 2015

Aceptado: marzo de 2016
} 
plantación agroforestal (coquia-mezquite) es técnicamente aceptable para este tipo de suelos, además de mostrar beneficios ambientales y económicos.

Palabras clave: producción de forraje, producción alternativa, salinidad de suelos.

\section{Introducción}

La agroforestería se aboca a los sistemas y tecnologías de uso del suelo en los cuales las especies leñosas perennes (árboles, arbustos, palmas, etc.) se utilizan deliberadamente en el mismo sistema de manejo que los cultivos agrícolas y la producción animal, en alguna forma de arreglo espacial o secuencia temporal. En los sistemas agroforestales existen interacciones tanto ecológicas como económicas entre los diferentes componentes.

El propósito del sistema es lograr un sinergismo entre los componentes, el cual conduce a mejoras netas en uno o más rangos, tales como la productividad y la sostenibilidad, así como a diversos beneficios ambientales y no-comerciales. Como ciencia, es multidisciplinaria y a menudo involucra, o debe involucrar, la participación de campesinos o agricultores en la identificación, diseño y ejecución de las actividades de investigación (Nair, 1993; ICRAF, 1996).

Los linderos maderables son siembras de árboles en línea en los límites de parcelas agropecuarias o fincas con el objetivo principal de producir madera o postes (CATIE, 1998). Rojas (2004) los define como sectores que delimitan las fincas de las propiedades vecinas o áreas internas de cultivos que además actúan como barreras rompevientos, cercas vivas y, a la vez, sirven como estrategia para la obtención de productos maderables de interés (madera y postes) y forestales derivados (leña, polen, belleza escénica, alimento para la fauna, etc.), entre otros bienes.

\section{Aguas residuales}

Hay cuatro fuentes de aguas residuales: domésticas o urbanas, industriales, de usos agrícolas y pluviales. Aunque la mayor parte (cerca de $90 \%$ ) proviene de las dos primeras, las de usos agrícolas y pluviales urbanas adquieren cada día mayor importancia debido a que los escurrimientos de fertilizantes (fosfatos) y pesticidas son los principales causantes del envejecimiento de lagos y pantanos, proceso llamado eutrofización.
Keywords: alternative production, forage production, soil salinity.

\section{Introduction}

The agroforestry systems and technologies of land use in which woody perennial species (trees, shrubs, palms, etc.) are deliberately used on the same system of handling agricultural crops and animal production in some form of spatial arrangement or temporal sequence. In agroforestry systems there are both ecological and economic interactions between different components.

The purpose of the system is to achieve a synergism between the components, which leads to net improvements in one or more ranges, such as productivity and sustainability, as well as various environmental and non-commercial benefits. As science is multidisciplinary and often involves, or should involve the participation of peasants or farmers in the identification, design and implementation of research activities (Nair, 1993; ICRAF, 1996).

The timber planting trees boundaries are online at the limits of agricultural plots or farms with the main objective of producing timber or poles (CATIE, 1998). Rojas (2004) defines as sectors that define the properties of neighboring properties or internal areas of crops that also act as windbreaks, living fences and, at the same time serve as a strategy for obtaining timber products of interest (wood and poles) and forest products (wood, pollen, scenic beauty, food for wildlife, etc.), among other goods.

\section{Sewage water}

There are four sources of wastewater: domestic or urban, industrial, agricultural uses and rain. Although most (about 90\%) comes from the first two, the urban agricultural and rainwater uses acquire ever greater importance due to runoff of fertilizers (phosphates) and pesticides are the main causes of aging of lakes and marshes, a process called eutrophication.

The wastewater is a mixture of organic and inorganic materials suspended or dissolved in water. Most of the former are food and vegetable waste, feces, mineral salts, soaps and synthetic detergents. Greater use of wastewater in agriculture is carried out in the Irrigation Districts 03 and 100 (Tula and Alfajayucan, respectively) located in 
El agua residual es una mezcla de materiales orgánicos e inorgánicos suspendidos o disueltos en el agua. La mayor parte de los primeros son desechos alimenticios y vegetales, heces, sales minerales, jabones y detergentes sintéticos. El mayor aprovechamiento de aguas residuales en la agricultura se realiza en los Distritos de Riego 03 y 100 (Tula y Alfajayucan, respectivamente) ubicados en el Valle del Mezquital, Hidalgo, donde se registra que desde hace 120 años se empezaron a utilizar estas aguas provenientes de la zona metropolitana de la Ciudad de México.

En la actualidad la superficie cultivada es de 91036 ha y se producen cultivos y forrajes como maíz, hortalizas, pastos, etc. Cada año se incrementa la disponibilidad de agua residual y la superficieregada(CONAGUA, 2008). Aunque en Tulancingo la contaminación del agua no adquiere todavía las dimensiones de los problemas que se tienen en las grandes ciudades del país, nose debe pasar por alto que existen elementos contaminantes que si no son atendidos con destreza se pueden convertir en un problema difícil de solucionar.

Tulancingo tiene un sistema insuficiente de drenaje sanitario, durante la temporada de lluvias suelen inundarse algunas zonas al brotar el agua de las atarjeas públicas y aun al interior de las viviendas. Se registra que desde hace 50 años, aproximadamente, elDR 028 hace uso de aguas residuales para el riego de 997 ha de cultivos forrajeros como alfalfa, pastos y maíz. Hoy ocupa el tercer lugar de superficie regada con aguas residuales del estado de Hidalgo (CONAGUA, 2009).

\section{Antecedentes}

\section{Contaminación de suelos}

Aunque el uso de aguas residuales en riego agrícola tiene ventajas como el incremento de nutrientes como nitrógeno $(\mathrm{N})$, fósforo $(\mathrm{P})$, potasio $(\mathrm{K})$ y materia orgánica $(\mathrm{MO})$, además de proporcionar humedad a los cultivos, también tiene desventajas cuando su uso es inadecuado o no se consideran las condiciones del suelo en las que serán utilizadas. Otra forma de contaminación del suelo por el uso de aguas residuales es la posible acumulación de metales pesados y la salinización (Montoya, 2010).

Carrillo et al. (1992) señalan que el uso de aguas residuales en el Valle del Mezquital provoca la introducción de los siguientes metales pesados al suelo: plomo $(\mathrm{Pb})$, cromo the Mezquital Valley, Hidalgo, where it is recorded that 120 years began to use these waters from the metropolitan area of Mexico City.

Today the cultivated area is 91036 ha and fodder crops such as corn, vegetables, grasses occur, etc. Each year the availability of residual water and irrigated area(CONAGUA, 2008) increases. Although Tulancingo water pollution has not yet acquired the dimensions of the problems are in large cities, should not be overlooked that there are contaminants that if they are not served with skill can become a difficult problem solve.

Tulancingo has insufficient sanitary sewer system during the rainy season usually flooded some areas the water sprout public sewers and even within homes. It is recorded that from about 50 years ago the DR 028 makes use of wastewater for irrigation has 997 forage crops such as alfalfa, grasses and corn. Today is third surface of irrigated with wastewater from Hidalgo (CONAGUA, 2009).

\section{Background}

\section{Soil contamination}

Although the use of waste water for agricultural irrigation has advantages such as increased nutrients such as nitrogen $(\mathrm{N})$, phosphorus $(\mathrm{P})$, potassium $(\mathrm{K})$ and organic matter $(\mathrm{MO})$, in addition to providing moisture to crops has disadvantages when its use is not considered inappropriate or soil conditions on which they are used. Another form of soil contamination by wastewater use is the possible accumulation of heavy metals and salinization (Montoya, 2010).

Carrillo et al.(1992) indicate that the use of wastewater in the Valle del Mezquital causes the introduction of the following heavy metals to soil: lead $(\mathrm{Pb})$, chromium $(\mathrm{Cr})$, cadmium $(\mathrm{Cd})$, nickel $(\mathrm{Ni})$, copper $(\mathrm{Cu})$, manganese $(\mathrm{Mn})$ and zinc ( $\mathrm{Zn})$ in different concentrations, which, when compared with the values of the heavy metals found in the well water, the excess over ten times concentration.

Regarding the type of crops that could be irrigated with treated water are known to the fruit, due to its high sensitivity to certain elements such as boron, chlorine and sodium, they are "prohibited" in irrigated areas with water containing high concentrations of the elements aforementioned. 
$(\mathrm{Cr})$, cadmio $(\mathrm{Cd})$, níquel $(\mathrm{Ni})$, cobre $(\mathrm{Cu})$, manganeso $(\mathrm{Mn})$ y zinc $(\mathrm{Zn})$ en diferentes concentraciones, las que, al ser comparadas con los valores de los metales pesados encontrados en el agua de pozo, los superan más de diez veces en concentración.

Respecto al tipo de cultivos que pudieran regarse con aguas tratadas se sabe que los frutales, debido a su alta sensibilidad a ciertos elementos como boro, cloro y sodio, se encuentran "prohibidos" en las zonas irrigadas con aguas que contengan altas concentraciones de los elementos antes mencionados.

Las hortalizas tienen un mayor rango de tolerancia a las aguas residuales, sin embargo, muchas de ellas que poseen contacto directo con el agua residual, como es el caso de la lechuga, la zanahoria, el betabel y el rábano, entre otras, pueden llegar a contaminarse con metales pesados y organismos fitopatógenos (como la Erwinia spp.) y las bacterias entéricas, que son aquellas que se encuentran en los intestinos del hombre y le causan enfermedades gastrointestinales (Sáenz, 1998).

Los elementos potencialmente tóxicos (EPT) son aquellos que se encuentran involucrados en procesos bioquímicos y toxicológicos (Tiller, 1989). Para su mejor ubicación, son todos aquellos metales de la tabla periódica con un número atómico mayor a 20, excluyendo los metales alcalinos y los alcalinotérreos. Este término se utiliza para clasificar a los metales que son contaminantes ambientales entre los que se encuentran: $\mathrm{Pb}, \mathrm{Cd}, \mathrm{Cu}, \mathrm{Zn}$ y Ni.

Según Gómez (2002), existen dos fuentes de los metales pesados en el suelo: la natural y la antropogénica. Los metales pesados contenidos en el material original o al meteorizarse, se concentran en los suelos. Concentraciones muy altas en los suelos pueden ocasionar acumulación de algún metal en plantas y causar efectos tóxicos para los animales que las consumen. También se deben considerar las actividades volcánicas, que emiten metales pesados como arsénico (As), mercurio (Hg) y selenio (Se) (Bradl, 2005).

El uso de aguas residuales en la agricultura puede aumentar el ingreso de MO y nutrientes a los suelos cultivados, lo cual contribuye a mantener e incrementar la fertilidad del mismo, pero también puede traer efectos ambientales nocivos que deterioran la calidad del suelo. Es decir, la dinámica de la materia orgánica en el suelo es importante ya que su descomposición influye en la liberación de moléculas orgánicas e inorgánicas enlazadas a ella (Zamora et al.,
Vegetables have a higher tolerance range wastewater, however, many of them that have direct contact with the waste water, such as lettuce, carrots, beets and radish, among others, can reach contaminated with heavy metals and plant pathogenic organisms (such as Erwinia spp.) and enteric bacteria, which are those found in the human intestines and cause gastrointestinal diseases (Sáenz, 1998).

The potentially toxic elements (EPT) are those who are involved in biochemical and toxicological processes (Tiller, 1989). For better location, are those metals of the periodic table with atomic number greater than 20 , excluding the alkali metals and alkaline. This term is used to classify metals are environmental contaminants among which are: $\mathrm{Pb}, \mathrm{Cd}, \mathrm{Cu}, \mathrm{Zn}$ and $\mathrm{Ni}$.

According to Gómez (2002), there are two sources of heavy metals in the soil: natural and anthropogenic. Heavy metals contained in the original material or unweathered, are concentrated in soils. Very high concentrations in soils may cause some metal accumulation in plants and cause toxic effects in animals that consume them. They should also be considered volcanic activities that emit heavy metals such as arsenic (As), mercury ( $\mathrm{Hg}$ ) and selenium (Se) (Bradl, 2005).

The use of wastewater in agriculture can increase income MO and nutrients to cultivated soils, contributing to maintaining and increasing soil fertility, but can also bring harmful environmental effects that impair soil quality. That is, the dynamics of organic matter in soil is important because decomposition influences the release of organic and inorganic molecules linked to it (Zamora et al., 2008). Therefore, the input sewage sludge for several years may modify the chemical features and soil fertility (Rovira et al., 2002).

\section{Materials and methods}

The irrigation district is located in the southeastern part of the state, between $20^{\circ} 05$ '01" north latitude; and $100^{\circ}$ $02^{\prime} 19^{\prime \prime}$ latitude east and between $98^{\circ} 22^{\prime}$ west longitude of Greenwich. It is 2140 meters above sea level and has an area of 997 ha of irrigation (INEGI, 1995). It includes the municipalities of Tulancingo, Santiago Tulantepec de Lugo Guerrero and Cuautepec de Hinojosa, in a proportion of $83.6 \%, 9.4 \%$ and $7 \%$ respectively (Figure 1 ). 
2008). Por tanto, la entrada del lodo de aguas residuales por varios años puede modificar las características químicas y de la fertilidad del suelo (Rovira et al., 2002).

\section{Materiales y métodos}

El Distrito de Riego se localiza en la zona sureste del estado, entre los $20^{\circ} 05^{\prime} 01^{\prime}$ ' de latitud norte; y $00^{\circ} 02^{\prime}$ ' 19 ' ' de latitud este y entre los $98^{\circ} 22^{\prime}$ de longitud oeste del Meridiano de Greenwich. Se encuentra a 140 msnm y tiene una extensión territorial de 997 ha de superficie de riego (INEGI, 1995). Incluye los los municipios de Tulancingo de Bravo, Santiago Tulantepec de Lugo Guerrero y Cuautepec de Hinojosa, en una proporción aproximada de $83.6 \%, 9.4 \%$ y $7 \%$ respectivamente (Figura 1).

Los predios sujetos a estudio se localizan en los ejidos San Nicolás Cebolletas, específicamente en el lugar que los habitantes llaman El Jagüey del Cerro y en el ejido Santa Ana del municipio de Tulancingo, en el estado de Hidalgo.

El Distrito de Riego presenta, según la clasificación climática de Köppen, modificada por García (2004), dos tipos de climas, $\mathrm{C}\left(\mathrm{w}_{1}\right)(\mathrm{w})$ y $\mathrm{BS}_{1} \mathrm{kw}$. El primero, templado subhúmedo con régimen de lluvias en verano, temperatura media anual entre 12 y $18^{\circ} \mathrm{C}$, con verano fresco largo, oscilación térmica menor de $5{ }^{\circ} \mathrm{C}$, marcha anual de la temperatura tipo Ganges, 1luvia anual de 43.2 a $55.3 \mathrm{~mm}$ por cada grado de temperatura media anual. Este se presenta en la zona de lomeríos principalmente.

El segundo, $\mathrm{BS}_{1} \mathrm{kw}$, seco templado semiárido con verano fresco largo, régimen de lluvias de verano, lluvia invernal entre 5 y $10 \%$ del total anual, temperatura media anual entre 12 y $18^{\circ} \mathrm{C}$, temperatura del mes más cálido menor a $18^{\circ} \mathrm{C}$. Este clima es predominante, se presenta principalmente en las partes bajas y planas del Distrito de Riego. El periodo de lluvia abarca desde el mes de junio hasta una parte de octubre y el de ausencia de lluvia es de noviembre a marzo, elevándose a partir de abril y mayo. La máxima precipitación se da en septiembre con $105.8 \mathrm{~mm}$ y la mínima en diciembre con $7 \mathrm{~mm}$ (ERIC III, 2006).

De acuerdo con la clasificación de la Dudal (1973), modificada por el INEGI (2000a), las unidades de suelos que se presentan en el distrito son regosoles, suelos poco desarrollados cuya formación generalmente depende de
The properties under study are located in the suburbs San Nicolás Chives, specifically in the place the locals call Jagüey of hill and in the common Santa Ana in the municipality of Tulancingo, in the state of Hidalgo.

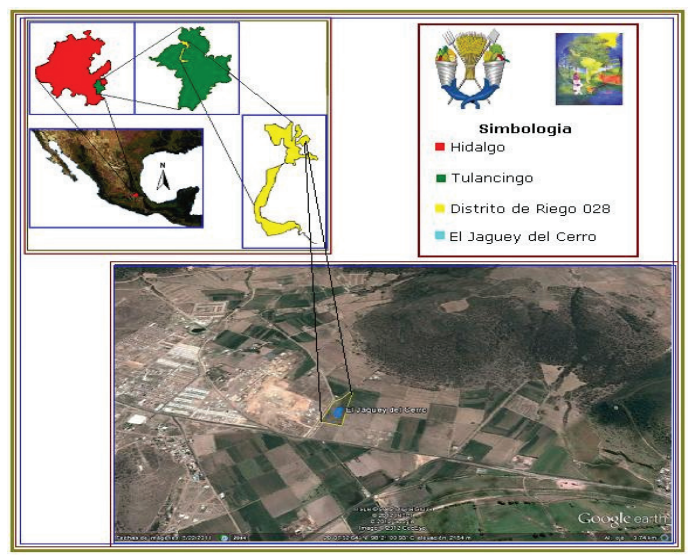

Figura 1. Ubicación del DR 028 Tulancingo, Hidalgo. Figure 1. Location of DR 028 Tulancingo, Hidalgo.

The irrigation district presents, according to Koppen climate classification, modified by García (2004), two types of climates, $\mathrm{C}\left(\mathrm{w}_{1}\right)(\mathrm{w})$ and $\mathrm{BS}_{1} \mathrm{kw}$. The first, tempered humid with rainfall in summer, annual average temperature between 12 and $18{ }^{\circ} \mathrm{C}$, with cool summer long, less temperature variation of $5{ }^{\circ} \mathrm{C}$, annual march of the Ganges type temperature, annual rainfall of 43.2 to $55.3 \mathrm{~mm}$ for each degree of mean annual temperature. This occurs in the area mainly mounds.

The second, $\mathrm{BS}_{1} \mathrm{kw}$, dry semiarid temperate with cool summer long, summer rainfall, winter rainfall between 5 and $10 \%$ of the annual total, annual average temperature between 12 and $18^{\circ} \mathrm{C}$, temperature of the warmest month less than $18^{\circ} \mathrm{C}$. This climate is predominant, it is mainly in the low and flat parts of the irrigation district. The rainy period runs from june to october one hand and the absence of rain is from november to march, rising from april and may. The maximum precipitation occurs in september with $105.8 \mathrm{~mm}$ and the minimum in december with $7 \mathrm{~mm}$ (ERIC III, 2006).

According to the classification of the Dudal (1973), as amended by the INEGI (2000a), the soil units presented in the district are regosols, poorly developed soils whose formation generally depends on the lithology as derived from the rock behind them. No clear differences have layers and have a very clear horizon ochric color and poor in organic matter, which overlies directly on rock or on a horizon C. 
la litología pues se derivan de la roca que les subyace. No presentan capas con diferencias claras y tienen un horizonte $\mathrm{A}$ ócrico muy claro en color y pobre en materia orgánica, el cual sobreyace directamente sobre roca o sobre un horizonte $\mathrm{C}$.

Las principales actividades dentro del Distrito de Riego son la agricultura de riego y la ganadería intensiva. Los cultivos son principalmente perennes como alfalfa forrajera, trébol y pasto forrajero, pero también hay cíclicos como maíz forrajero, avena, frijol, chiles, tomate, calabaza, etc. La actividad ganadera se lleva a cabo mediante pequeñas unidades de producción bovina, principalmente de traspatio. Esta actividad absorbe la producción forrajera (CONAGUA, 2009). Cabe mencionarque debido a la cercanía con la ciudad de Tulancingo el distrito ha sido invadido por la mancha urbana, lo que ha provocado fragmentación y abandono de las áreas de cultivo.

La presente investigación se dividió en tres fases: de gabinete, que consistió en planificar y organizar talleres participativos y, como segunda tarea, Investigación de campo, que comprendió la delimitación del área de muestreo, muestreo y el establecimiento de un experimento de laboratorio que implicó la ejecución de los análisis físicos y químicos de los suelos; y la tercera fue el análisis de la información obtenida.

De acuerdo con el padrón de usuarios de aguas negras, el módulo está integrado por cinco ejidos: Santa Ana Hueytlalpan, San Nicolás Cebolletas, Tulancingo, La Laguna y Santa María. Se encuentran registrados dentro del padrón un total de 228 usuarios y la superficie total de praderas regadas con aguas negras es de 512.4 ha.

Según la CONAGUA (2009), en el DR 028 existe una modalidad de producción basada en el riego. Se tiene registrada una superficie de 997 ha con una producción total de $37068 \mathrm{taño}^{-1}$. Hay dos tipos de riego: por gravedad o rodado y rodado mediante bombeo.

\section{Resultados y discusión}

\section{Determinaciones químicas en suelo}

El pH medido va de moderadamente alcalino a alcalino, según la (NOM-021-RECNAT, 2000). Los valores para las muestras obtenidas son: en El Jagüey del Cerro, 7.62, y
The main activities within the irrigation district are irrigated agriculture and intensive farming. Perennial crops are mainly as forage alfalfa, clover and grass forage, but there are also cyclical and fodder corn, oats, beans, peppers, tomatoes, squash, etc. The cattle activity is carried out by small cattle production units, mainly backyard. This activity absorbs forage production (CONAGUA, 2009). It is worth mentioning that due to the proximity to the city of Tulancingo the district has been invaded by urban sprawl, which has led to fragmentation and abandonment of farming areas.

This research was divided into three phases: cabinet, which was to plan and organize participatory workshops and as a second task, field research, which involved the delimitation of the sampling area, sampling and the establishment of a laboratory experiment involving the execution of physical and chemical analysis of soils; and the third was the analysis of the information obtained.

According to the user registry sewage, the module is composed of five suburbs Hueytlalpan Santa Ana, San Nicolás Cebolletas, Tulancingo, La Laguna and Santa María. They are registered in the register a total of 228 users and the total area of pastures irrigated with sewage is 512.4 ha.

According to the CONAGUA (2009), in the DR 028 there is a mode of production based on irrigation. It has registered an area of 997 hectares with a total production of $37068 \mathrm{t}$ $\mathrm{yr}^{-1}$. There are two types of irrigation: by gravity or rolled and by pumping rolled.

\section{Results and discussion}

\section{Chemical determinations in soil}

The measured $\mathrm{pH}$ is moderately alkaline to alkaline, according to (NOM-021-RECNAT, 2000). The values for samples collected are: Jagüey del Cerro, 7.62, and 8.20 in Tulancingo Santa Ana. The sample obtained in the first no salinity problems $\left(0.79 \mathrm{~S} \mathrm{~m}^{-1}\right)$. Meanwhile in Santa Ana if any $\left(4.86 \mathrm{~S} \mathrm{~m}^{-1}\right)$.

As for the permanence of organic matter in the soil, it is transient and continuously renewed by the addition of plant residues or other (Ramos, 2000). The Jagüey del Cerro the content is very low $(0.27 \%)$ and Santa Ana sample is low 
para Santa Ana Tulancingo 8.2. La muestra obtenida en el primero no presenta problemas de salinidad $\left(0.79 \mathrm{~S} \mathrm{~m}^{-1}\right)$. En tanto en Santa Ana sí los hay $\left(4.86 \mathrm{~S} \mathrm{~m}^{-1}\right)$.

En cuanto a la permanencia de materia orgánica en el suelo, es transitoria y renovada continuamente por la adición de residuos vegetales u otros (Ramos, 2000). En El Jagüey del Cerro el contenido es muy bajo $(0.27 \%)$ y en la muestra de Santa Ana es bajo (1.34\%). Las concentraciones de nitrógeno inorgánico fueron bajas tanto en El Jagüey del Cerro (13.8 $\mathrm{mg} \mathrm{kg}{ }^{-1}$ ) como en Santa Ana (18.4 $\mathrm{mg} \mathrm{kg}^{-1}$ ).

El fósforo en El Jagüey del Cerro, donde el riego es por bombeo, se encuentra clasificado como moderadamente bajo (12.05 mg kg ${ }^{-1}$ ), a diferencia de Santa Ana donde es muy alto $\left(125.86 \mathrm{mg} \mathrm{kg}^{-1}\right)$. Con relación a las concentraciones de potasio en el suelo, se observó que son considerablemente altas en las dos muestras.

Los niveles de calcio en los suelos fluctúan de medio (1807 $\left.\mathrm{mg} \mathrm{kg}{ }^{-1}\right)$ en El Jagüey del Cerro y alto $\left(4321 \mathrm{mg} \mathrm{kg}^{-1}\right)$ en SantaAna. En las dos muestras se presentan concentraciones que van de moderadamente altas a altas de $\mathrm{Fe}$ (22.4 a 28.7 $\mathrm{mg} \mathrm{kg}^{-1}$ ) y Mn (27.18 a $\left.26.6 \mathrm{mg} \mathrm{kg}^{-1}\right)$; de igual forma se obtuvo que para el $\mathrm{Cu}\left(0.9\right.$ a $\left.2.12 \mathrm{mg} \mathrm{kg}^{-1}\right)$ y $\mathrm{Zn}(1.6$ a 4.86 $\left.\mathrm{mg} \mathrm{kg}^{-1}\right)$ se presentan concentraciones de medias a altas. El boro es necesario en pequeñas cantidades para el desarrollo de los cultivos, promueve la germinación de los granos de polen, el crecimiento del tubo polínico y la formación de semillas y paredes celulares. Es el micronutriente que más frecuentemente aparece como limitante para las plantas y es el más utilizado como fertilizante.

La concentración de boro en El Jagüey del Cerro se encuentra en niveles altos $\left(1.49 \mathrm{mg} \mathrm{kg}^{-1}\right)$ y en Santa Ana en niveles clasificados como muy altos ( $\left.3.05 \mathrm{mg} \mathrm{kg}^{-1}\right)$, lo cual indica toxicidad para cultivos sensibles que sean establecidos en estos sitios. Según Vázquez (1997), en general se cubren los requerimientos de boro para los cultivos presentes en la zona. Respecto a la textura, los resultados obtenidos en El Jagüey del Cerro corresponden a un suelo franco y en Santa Ana a uno franco arcilloso.

\section{Elementos potencialmente tóxicos (EPT): $\mathrm{Pb}, \mathrm{Cd}, \mathrm{y} \mathrm{Cr}$}

La solubilidad de varios elementos, entre ellos $\mathrm{Pb}, \mathrm{Cd}$ y $\mathrm{Cr}$, se relaciona inversamente con el $\mathrm{pH}$ (Mc Bride et al., 1997). Los suelos de El Jagüey del Cerro y Santa Ana presentaron bajas concentraciones: para $\mathrm{Pb}$, de 1.1 y 1.06
$(1.34 \%)$. Inorganic nitrogen concentrations were low in both Jagüey of hill (13.8 $\left.\mathrm{mg} \mathrm{kg}^{-1}\right)$ and Santa Ana (18.4 mg $\left.\mathrm{kg}^{-1}\right)$.

The phosphorus in the Jagüey del Cerro of hill, where irrigation is pumped classified as moderately low (12.05 $\left.\mathrm{mg} \mathrm{kg}^{-1}\right)$ it is, unlike Santa Ana where it is very high (125.86 $\left.\mathrm{mg} \mathrm{kg}^{-1}\right)$. With regard to the concentrations of potassium in the soil, it was observed that are considerably high in the two samples.

The calcium levels in the soil fluctuate medium $(1807 \mathrm{mg}$ $\mathrm{kg}^{-1}$ ) in Jagüey of hill and high (4321 mg kg-1) in Santa Ana. In the two samples concentrations ranging from moderately high to high with presents $\mathrm{Fe}$ ( 22.4 to $28.7 \mathrm{mg} \mathrm{kg}^{-1}$ ) and $\mathrm{Mn}$ (27.18 to $\left.26.6 \mathrm{mg} \mathrm{kg}^{-1}\right)$; similarly it was obtained for $\mathrm{Cu}(0.9$ to $2.12 \mathrm{mg} \mathrm{kg}^{-1}$ ) and $\mathrm{Zn}$ (1.6 to $4.86 \mathrm{mg} \mathrm{kg}^{-1}$ ) medium to high concentrations occur. The boron is needed in small quantities for crop development it promotes the germination of pollen grains, pollen tube growth and seed formation and cell walls. It is the most common micronutrient that appears as limiting for plants and is the most used as fertilizer.

The concentration of boron in Jagüey del Cerro is found at high levels $\left(1.49 \mathrm{mg} \mathrm{kg}^{-1}\right)$ and in Santa Ana at levels classified as very high $\left(3.05 \mathrm{mg} \mathrm{kg}^{-1}\right)$, indicating toxicity to sensitive crops are established in these sites. According to Vázquez (1997) general requirements for crops boron present in the area covered. Regarding the texture, the results of Jagüey of hill correspond to a loam and one in Santa Ana clay loam.

\section{Potentially toxic elements (EPT): $\mathrm{Pb}, \mathrm{Cd}$, and $\mathrm{Cr}$}

The solubility of several elements, including $\mathrm{Pb}, \mathrm{Cd}$ and $\mathrm{Cr}$, is inversely related to the $\mathrm{pH}$ (Mc Bride et al., 1997). The soils of Jagüey del Cerro and Santa Ana had low concentrations: for $\mathrm{Pb}, 1.1$ and $1.06 \mathrm{mg} \mathrm{kg}^{-1}$, respectively, and 1.62 and $0.23 \mathrm{Cd} \mathrm{mg} \mathrm{kg}^{-1}$. The samples are below the values considered critical; according to the established by the US-EPA (1993) they are not contaminated soils. Similarly, subject to the NOM-021-RECNAT-2000, the concentrations of these elements are not present a problem of toxicity to plants.

Ramos et al. (2001) concluded that the content of heavy metals in soils irrigated with wastewater will depend on the concentration containing these waters at the time of irrigation and time you have to use them, this relates to the 
$\mathrm{mg} \mathrm{kg}{ }^{-1}$ respectivamente, y para $\mathrm{Cd}$ de 1.62 y $0.23 \mathrm{mg}$ $\mathrm{kg}^{-1}$. Las muestras se encuentran por debajo de los valores considerados críticos; de acuerdo a lo establecido por la USEPA(1993) no son suelos contaminados. De igual forma, con apego a la NOM-021-RECNAT-2000, las concentraciones de estos elementos no presentan un problema de toxicidad para las plantas.

Ramos et al.(2001) concluyeron que el contenido de metales pesados en suelos regados con aguas residuales va a depender de la concentración que contengan esas aguas al momento del riego y del tiempo que se tenga utilizándolas, esto se relaciona con los resultados obtenidos en el presente trabajo ya que la baja concentración deEPT puede estar directamente relacionada con el agua que se utiliza para riego.

Apesar de no encontrar problemas con los EPT se requiere el monitoreo continuo de los suelos para detectar cualquier tipo de problema que se llegue a presentar con relación a ellos.

\section{Establecimiento del sistema coquia-mezquite}

En la zona del Jagüey del Cerro el diseño del sistema agroforestal (coquia-mezquite) tuvo como base de su arreglo la problemática manifestada por los productores involucrados en el proyecto durante los talleres: dada la situación topológica del terreno, el riego resulta demasiado caro ya que se tiene que bombear y por ende los costos se incrementan.

El establecimiento de las especies coquia agrícola y mezquite forestal se realizó al inicio del periodo de lluvias, con planta de calidad, en cepas de $40 \mathrm{~cm}$ de profundidad y $40 \mathrm{~cm}$ de diámetro excavadas con pala. Antes de plantar se colocó en el fondo de la cepa abono orgánico, con un diseño de linderos maderables. La Figura 2 indica el arreglo espacialy temporal de las especies en el sistema agroforestal; este sólo contempla el manejo de podas cuyo propósito es la formación de un tronco lo más grueso y derecho posible mediante la eliminación de las ramas que nacen en la base de la planta.

Este sistema intenta un manejo holístico de los recursos naturales, al asociar en un mismo terreno y de forma planeada una vegetación herbácea para la alimentación del ganado, con vegetación arbustiva y/o arbórea que pueda proveer impactos positivos sobre el ambiente y satisfactores que generen un ingreso adicional para el productor rural, como madera, leña, resinas, frutas, etc (Musálem, 2001). results obtained in this work and the low concentration of EPT can be directly related to the water used for irrigation. Despite not finding problems with EPT continuous monitoring of soils it is required to detect any problem that comes to file in relation to them.

\section{Establishment of kochia-mesquite system}

In the area of Jagüey del Cerro design agroforestry system (kochia-mesquite) had as a basis for settlement the problems expressed by the producers involved in the project during the workshops: given the topological location of the land, irrigation is too expensive and that must be pumped and thus costs increase.

The establishment of species agricultural kochia and forestry mesquite was made at the start of rainy season, with plant quality, strains $40 \mathrm{~cm}$ deep and $40 \mathrm{~cm}$ in diameter dug with a shovel. Before planting was placed in the bottom of the compost strain, with a design of timber boundaries. Figure 2 shows the spatial and temporal arrangement of the species in the agroforestry system; This only covers the management of pruning's whose purpose is the formation of a thick trunk as possible and right by removing branches that are born at the base of the plant.

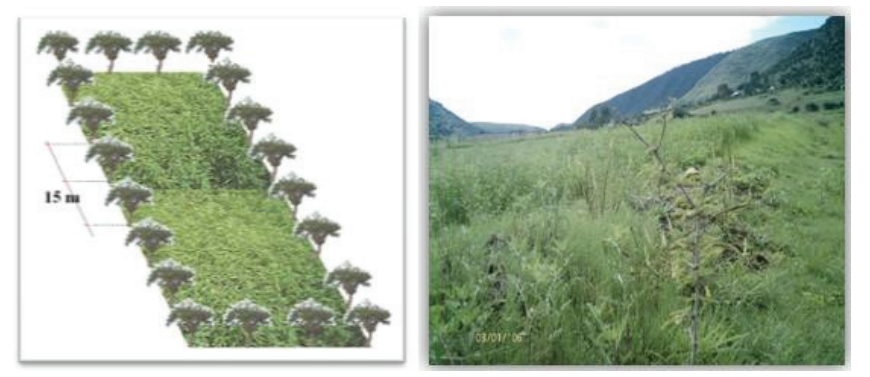

Figura 2. Diseño espacial de la plantación agroforestal de acuerdo con las especies de árboles y cultivo agrícolas en el DR 028 Tulancingo, Hidalgo.

Figure 2. Spatial design of agroforestry plantation according to tree species and agricultural crops in the DR 028 Tulancingo, Hidalgo.

This system attempts a holistic management of natural resources, associating in the same spot without planned herbaceous vegetation for cattle feed, Shrub and/or vegetation tree that can provide positive impacts on the environment and satisfactions that generate additional income for rural producers, such as wood, wood, resins, fruits, etc (Musálem, 2001). 


\section{Costo de establecimiento del sistema agroforestal coquia- mezquite}

El valor de la inversión inicial actual para establecer una hectárea de sistema agroforestal coquia-mezquite fue de $\$ 5$ 890.00. Sin contemplar la adquisición de la carreta y el caballo para transportar el forraje cosechado, con un costo estimado de $\$ 7000.00$ que, al sumarse, da una inversión inicial de $\$ 12890.00$ (Cuadro 1).

No se contempla al subsoleo y algunas otras actividades porser menos frecuentes. En contraparte, el costo de establecimiento de una hectárea de pradera de alfalfa, cultivo dominante en la zona, es de $\$ 12058.00$, esto según Pérez(2011), quien realizó una evaluación económica del uso de aguas residuales en el módulo II del Distrito de Riego 028 Tulancingo, Hidalgo.

\section{Cost of establishment of agroforestry system kochia -mezquite}

The current value of the initial investment to establish one hectare of agroforestry system kochia-mesquite was $\$ 5$ 890.00. Without considering the acquisition of the cart and the horse to transport the harvested forage at an estimated cost of $\$ 7000.00$ which, when added, gives an initial investment of $\$ 12890.00$ (Table 1).

It does not include the subsoiling and some other activities to be less frequent. In contrast, the cost of establishing a hectare of alfalfa, dominant crop in the area, is $\$ 12058.00$, this according to Pérez (2011), who conducted an economic assessment of the use of wastewater in the module II District 028 irrigation Tulancingo, Hidalgo.

Cuadro 1. Costo de establecimiento de una hectárea de sistema agroforestal coquia-mezquite en el DR 028 Tulancingo, Hidalgo.

Table 1. Cost of establishing a hectare of kochia-mesquite agroforestry system in the DR 028 Tulancingo, Hidalgo.

\begin{tabular}{|c|c|c|c|c|}
\hline Concepto & Núm. de jornales & Cantidad & Costo unitario & Costos \\
\hline I. Preparación del suelo & & & & $\$ 2410.00$ \\
\hline 1. Barbecho & & 1 & $\$ 400.00$ & $\$ 400.00$ \\
\hline 2. Rastreo & & 2 & $\$ 375.00$ & $\$ 750.00$ \\
\hline 3. Trazo de melgas & 4 & & $\$ 140.00$ & $\$ 560.00$ \\
\hline 4. Otras labores (delimitación, limpia, etc.) & 5 & & $\$ 140.00$ & $\$ 700.00$ \\
\hline \multicolumn{5}{|l|}{5 (delimitación, limpia, etc.) } \\
\hline II. Siembra & & & & $\$ 3480.00$ \\
\hline 1. Semillas (coquia) & & $8 \mathrm{Kg}$ & $\$ 150.00$ & $\$ 1200.00$ \\
\hline 2. Mano de obra (yunta) & & & $\$ 140.00$ & $\$ 280.00$ \\
\hline 3. Plantones de mezquite & & 40 & $\$ 50.00$ & $\$ 2000.00$ \\
\hline Total & & & & $\$ 5890.00$ \\
\hline
\end{tabular}

Fuente: elaboración con base en los costos de establecimiento.

El rendimiento de una hectárea de coquia fue de $46.7 \mathrm{t}$. El Instituto de Ciencia y Tecnología Agrícolas (ICTA, 2002) afirma que la coquia (Kochia scoparia) ha demostrado tener un alto potencial forrajero, siendo su producción de materia verde de $56 \mathrm{t} \mathrm{ha}^{-1}$. Es una planta que se adapta a una gran diversidad de climas, es tolerante a los suelos salinos y las bajas temperaturas (Anaya, 2004). Es de alta palatabilidad, especialmente por su gustosidad, buena digestibilidad y baja en fibra. Tiene un porcentaje de proteína cruda de 18 a $28 \%$.

Comparativamente, según Pérez (2011), una hectárea de alfalfa, cultivo dominante en la zona, tiene una producción que varía entre $25.85 \mathrm{t}$ en primavera y $34.5 \mathrm{t}$ en verano;
The yield of one hectare of kochia was $46.7 \mathrm{t}$. The Instituto de Tecnología del Agua (ICTA, 2002) states that kochia (Kochia scoparia) has shown a high forage potential, and its production of green matter of $56 \mathrm{t} \mathrm{ha}^{-1}$. It is a plant that adapts to a wide variety of climates it is tolerant to saline soils and low temperatures (Anaya, 2004). It is high palatability, especially its palatability, good digestibility and low in fiber. It has a percentage of crude protein of 18 to $28 \%$.

Comparatively, according to Pérez (2011), one hectare of alfalfa, dominant crop in the area, has a production ranging between 25.85 and $34.5 \mathrm{t}$ spring in summer; added to this the kochia requires four to six times less water than 
aunado a esto la coquia requiere de cuatro a seis veces menos agua que la alfalfa, y tiene rendimientos superiores a ésta. Es así, más que evidente, la viabilidad de la coquia como cultivo forrajero en la zona (Gutiérrez, 2000).

En cuanto al mezquite, que tiene una sobrevivencia de $100 \%$, Franco et al. (2006) comentan que debido a su bajo requerimiento de agua reviste gran parte de las regiones áridas y se establece en suelos con alto contenido en sales, aunque también se desarrolla en suelos arcillosos y aporta madera y forraje.

Colocar mezquites en los linderos del terreno trae consigo beneficios CATIE (1998), logran una delimitación clara y segura de la finca, evitando posibles conflictos legales con los colindantes; producen madera sin interferir con la cosecha, actúan como barreras de protección contravientos, aumentan la belleza escénica de la finca, su fruto también es consumido como alimento humano; el follaje, al igual que las vainas, alimenta el ganado, especialmente durante la sequía o escasez de otros forrajes.

Ramírez (2002) menciona algunos de los errores más comunes que se cometen al incorporar árboles maderables a los linderos de los terrenos, los cuales afectan directamente las ganancias tanto económicas como ecológicas. Estos son: no efectuar labores de resiembra, no hacer podas, no realizar raleos, sobrepoda (mutilar o desmochar), anillar los árboles, no esperar los turnos de corta adecuados para cosecharlos, y colocar los hilos de las cercas (alambre de púas) directamente sobre los troncos.

\section{Conclusiones}

Los talleres participativos permitieron definir las necesidades de los productores respecto a la baja producción e ineptitud que presentan sus terrenos. Establecer la falta de prácticas agrícolas en sus cultivos, además de acordar el establecimiento del sistema agroforestal (coquia-mezquite) como una alternativa para mejorar la producción actual.

La caracterización física y química de los suelos reveló que los contenidos nutrimentales son de medios a altos (con excepción del nitrógeno), que la materia orgánica se presenta en rangos de muy pobres a pobres, y que los contenidos de metales pesados no se consideran críticos para la producción alfalfa, and has higher yields than this. Thus, more than obvious, the feasibility of kochia as a forage crop in the area (Gutiérrez, 2000).

As mesquite, which has a 100\% survival, Franco et al.(2006) note that due to its low water requirement of great part of arid regions and is set to soils with high salt content, but also develops in clay soils and provides wood and fodder.

Place mesquite on the edge of the land brings benefits CATIE (1998), achieved a clear and safe boundaries of the property, avoiding possible legal conflicts with neighboring; produce timber without interfering with the harvest, act as barriers windbreak protection, increase the scenic beauty of the farm and its fruit is also consumed as food; foliage, like pods, feeding livestock, especially during drought or other fodder shortages.

Ramírez (2002) mentions some of the most common mistakes made by incorporating timber to the boundaries of the land, which directly affect both economic and ecological gains. These are not performing work reseeding, do pruning, not perform thinning, repruning (maul or desmochar), "anillar" trees, not wait shifts adequate short to harvest them, and place the wires fences (barbed wire) directly on the trunks.

\section{Conclusions}

The participatory workshops allowed to define the needs of the producers to low production and ineptitude presenting their land. Set the lack of agricultural practices on their crops, in addition to agreeing the establishment of agroforestry system (kochia-mesquite) as an alternative to improve current production.

The soil chemistry and physical characterization revealed that the nutritional contents are medium to high (except nitrogen), the organic matter is presented in ranges from very poor to poor, and that the contents of heavy metals are not considered critical for the production of crops or represent environmental risk; similarly it found that salinity occurs in some soils.

Based on soil conditions they presented agroforestry system (kochia-mesquite) was implemented, for being two-tolerant crops such soil properties. The results showed that the 
de los cultivos ni representan riesgo ambiental; de igual forma se comprobó que la salinidad se presenta en algunos suelos.

Con base en las condiciones que presentaron los suelos se implementó el sistema agroforestal (coquia-mezquite), por ser dos cultivos tolerantes a dichas propiedades del suelo. Los resultados mostraron que el sistema agroforestal es una alternativa para la producción de forraje y especies maderables en los suelos del DR 028 Tulancingo, Hidalgo.

\section{Literatura citada}

Anaya, G. M. 2004. Siembra aérea de Kochia scoparia en la zona federal del ex-lago de Texcoco. Reporte técnico. Colegio de Postgraduados. Campus Montecillo. 29 p.

Bradl, H.A. 2005. Heavy metals in the environment. University of Applied Sciences TrierNeubrucke, Germany. 269 p.

Carrillo, G. R. J.; Cajuste, L. y Hernández, L. H. 1992. Acumulación de metales pesados en un suelo regado con aguas residuales. Soc. Mexicana de la Ciencia del Suelo. Terra 10(2):166-173.

CATIE. 1998. Plantaciones de árboles en líneas. CATIE/GTZ, Turrialba, Costa Rica. 117 p.

CONAGUA. 2008. Estadísticas del agua en México. Semarnat. México, D. F. 231 p.

CONAGUA. 2009. Distrito de Riego 028 de Tulancingo, Hidalgo. Plan de Riego 2009-2010.

ERIC III. 2006. Instituto Mexicano de la Tecnología del Agua (IMTA). Versión CD- ROM 121 pp.

Dudal, R. 1973. Definiciones de las unidades de suelos para el mapa de suelos del mundo. In: Boletín de los recursos de suelos del mundo. Núm. 33. FAO.

García E. 2004. Modificaciones al sistema de clasificación climática de Köppen. 5a. ed. Instituto de Geografía. Universidad Nacional Autónoma de México (UNAM). México. 65 p.

Gómez, V.M. I. 2002. Especies arvenses con capacidad para remover Cd, $\mathrm{Pb}$ y $\mathrm{Zn}$ de los suelos del Valle del Mezquital, Hidalgo. Tesis de licenciatura. Universidad Autónoma Chapingo (UACH), Chapingo, Estado de México. $76 \mathrm{p}$.

Gutiérrez, L. A. 2000. Comparación forrajera de Quinua coquia y alfalfa bajo condiciones de riego y sequía. Unidad Regional Universitaria de Zonas Áridas. Bermejillo, Durango. Tesis profesional. $92 \mathrm{p}$.

ICRAF. 1996. Annual Report, ICRAF, Nairobi, Kenya 44 p.

INEGI. 1995. Instituto Nacional de Estadística Geografía e Informática. Fotografías aéreas (f14d82c y f14d82f) escala 1:75000. Aguascalientes, México. 498 p.

INEGI. 2000a. Clima. Conjunto de datos vectoriales de la carta geológica, escala 1:250 000. Serie I. Aguascalientes, México.586 p.

Franco, Y. L. L.; Goycoolea, F. M.; Valdez, M. A. y de la Barca, A. C. 2006. Goma de mezquite: una alternativa de uso industrial. Interciencia: 31(3):183-189. agroforestry system is an alternative for the production of fodder and timber species in the soils of DR 028 Tulancingo, Hidalgo.

\section{End of the English version}

McBride, M.; Sauve, S. and Hendershot, W. 1997. Solubility control of $\mathrm{Cu}, \mathrm{Zn}, \mathrm{Cd}$ and $\mathrm{Pb}$ in contaminated soils. Eur. J. Soil Sci. 48(2):337-346.

Montoya-Reyes F. 2010. Características físicas y químicas de suelos regados con aguas residuales del Distrito de Riego 028 y metales pesados en Medicago sativa. Tesis profesional. Universidad Autónoma Chapingo (UACH), Chapingo, Estado de México. $276 \mathrm{pp}$.

Musálem, S. 2001. Sistemas agrosilvopastoriles: una alternativa de desarrollo rural para el trópico mexicano Universidad Autónoma Chapingo(UACH). División de Ciencias Forestales. Chapingo, Estado de México. 95 p.

Nair, P. K. R. 1993. Tree-crop interactions in sustainable agroforestry systems. In: XV World Congress of Soil Science. Acapulco, México $255 \mathrm{p}$.

Pérez, V. S. 2011. Evaluación económica del uso de aguas residuales en el módulo II del Distrito de Riego 028, Tulancingo, Hgo. Tesis profesional. UniversidadAutónoma Chapingo(UACH), Chapingo, Estado de México. 99 p.

Ramírez, P. B. L. 2002. Caracterización y alternativas productivas para fincas ganaderas establecidas en la Amazonia Colombiana. Agroforestería en las Américas (CATIE). 9:33-34.

Ramos, M. C. 2000. Propiedades físicas y químicas de los suelos del Campo Agrícola Experimental Chapingo, tablas San Martín y Xaltepa. Tesis profesional, Universidad Autónoma Chapingo (UACH), Chapingo, Estado de México. 112 p.

Ramos, B. R.; Cajuste, L.; Flores, D. y García, N. 2001. Metales pesados, sales y sodio en suelos de chinampa en México. Agrociencia. 35:385-395.

Rojas, F.; Canessa, R. y Ramírez, J. 2004. Incorporación de árboles y arbustos en los cafetales del Valle Central de Costa Rica. Cartago, CR, ICAFE/ITCR. 390 pp.

Sáenz, F. R. 1998. Introducción y uso de aguas residuales tratadas en agricultura y acuicultura. In: OPS. Modernización y avances en el uso de aguas negras para la irrigación: intercambio de aguas uso urbano y riego. Washington, D. C. 86 pp.

Rovira, P. S.; Brunetti, G.; Polo, A. and Senesi, N. 2002. Comparative chemical and spectroscopic characterization of humic acids from sewage sludges and sludge-amended soils. Soil Sci. 167(4):235-245.

Tiller, K. G. 1989. Heavy metals in soils and their environmental significance. In Advances in soil science Springer US. 113-142 pp.

Vázquez, A. A. 1997. Guía para interpretar el análisis químico del agua y suelo. 2a . edición. Universidad Autónoma Chapingo (UACH). $31 \mathrm{p}$.

Zamora, F.; Rodríguez, N.; Rodríguez, D. T. y Yendis, H. 2008. Efecto del riego con aguas residuales sobre propiedades químicas de suelos de la planicie de Coro, Estado Falcón. Bioagro. 20(3):193-199. 